Jurnal Ilmu Sosial dan Pendidikan (JISIP)

Vol. 5 No. 3 Juli 2021

Terakreditasi Peringkat 5 (No. SK: 85/M/KPT/2020)

e-ISSN : 2656-6753, p-ISSN: 2598-9944

DOI: 10.36312/jisip.v5i3.2227 /http://ejournal.mandalanursa.org/index.php/JISIP/index

\title{
Dampak Pandemi Covid-19 Terhadap Pengangguran Di Indonesia
}

\author{
Verina Ruth Krisnandika ${ }^{1}$, Darlin Aulia ${ }^{2}$,Luluul Jannah ${ }^{3}$ \\ ${ }^{1,2,3}$ Sekolah Tinggi Media Nusantara Citra
}

\begin{abstract}
Article Info
Article history:

Article Reseived : 23July 2021

Publication: 23 July 2021
\end{abstract}

\section{Keywords:}

Pandemi

Covid-19,

Pengangguran

Indonesia

\begin{abstract}
Penelitian ini melihat pengaruh pandemic covid-19 terhadap pengangguran di Indonesia. Metode penelitian yang digunakan adalah metode kualitatif. Data yang digunakan dalam penelitian ini adalah data sekunder berupa jurnal ilmiah. dengan literatur review. Hasil analisis menunjukkan bahwa jumlah pengangguran yang terjadi di Indonesia terus meningkat seiring adanya pandemi COVID-19, dari data jumlah pekerja yang di-PHK dari sektor formal dan informal terlihat bahwa jumlah pekerja yang di-PHK dan dirumahkan bertambah secara tidak normal dan hal itu dapat menyebabkan banyak sekali pekerja yang menganggur. Adapun beberapa upaya yang dapat dilakukan untuk mengatasi hal tersebut seperti mengeluarkan kebijakan moneter dengan menurunkan suku bunga untuk meringankan biaya pinjaman bagi masyarakat, mengeluarkan kebijakan fiskal dengan memotong pajak dan meningkatkan pengeluaran negara supaya perekonomian Indonesia membaik, memberikan pelatihan kerja melalui program Kartu PraKerja supaya pekerja yang terkena PHK dapat bekerja lagi dan meningkatkan jumlah penduduk bekerja dll. This is an open access article under the Lisensi Creative Commons Atribusi-BerbagiSerupa 4.0 Internasional
\end{abstract}

\section{Corresponding Author:}

Verina Ruth Krisnandika

Sekolah Tinggi Media Nusantara Citra (STIE MNC)

Email: ruth.verina@gmail.com

\section{PENDAHULUAN}

Indonesia menjadi salah satu negara yang terdampak pandemi COVID-19, dengan kasus tersebut pertama kali muncul pada awal bulan Maret 2020 dan masih berlangsung hingga saat ini. Pandemi ini menyebabkan banyak kematian dan Indonesia menempati peringkat ketiga jumlah kematian akibat COVID-19 terbanyak di Asia (Worldometer, 2020). Sebagai tanggapan terhadap pandemi COVID-19 tersebut, pemerintah memberlakukan Pembatasan Sosial Berskala Besar (PSBB) di sebagian besar wilayah di Indonesia. PSBB yang dimaksud adalah pembatasan kegiatan tertentu penduduk dalam suatu wilayah yang diduga terinfeksi penyakit dan/atau terkontaminasi sedemikian rupa untuk mencegah kemungkinan penyebaran penyakit atau kontaminasi, (PerMenKes No. 9 Tahun 2020). Hal ini dilakukan untuk mencegah kemungkinan penyebaran makin meluas. Dalam masa PSBB, sejumlah kegiatan yang melibatkan publik dibatasi, misalnya beberapa sektor perkantoran atau instansi diliburkan, pembatasan kegiatan keagamaan, dan pembatasan transportasi umum. Pemerintah juga mengeluarkan kebijakan untuk Work from Home (WFH) dan School from Home (SFH).

Akibat terjadinya pandemi COVID-19 dan PSBB ini, Indonesia mengalami penurunan pendapatan, pelemahan nilai tukar rupiah, dan perlambatan pertumbuhan ekonomi. Pertumbuhan ekonomi Indonesia mengalami penurunan sebagai dampak dari PSBB yang membuat aktivitas masyarakat dalam kegiatan ekonomi menjadi terbatas (Rizal, 2020). Oleh karena itu, kinerja 
perekonomian yang mengalami penurunan ini juga mempengaruhi ketenagakerjaan di Indonesia, yakni meningkatnya jumlah pengangguran. Dampak pandemi COVID-19 berimbas pada semua sektor ekonomi seperti sektor pariwisata, sektor rumah tangga, sektor UMKM, sektor keuangan dan sebagainya (Firdaus, 2020). Sektor-sektor yang mungkin masih menyerap tenaga kerja di masa pandemi ini adalah jasa pendidikan, informasi dan komunikasi, jasa kesehatan dan kegiatan sosial, serta jasa keuangan dan asuransi. Sedangkan, menurut Bappenas (Badan Perencanaan Pembangunan Nasional) tahun 2020, sektor yang akan banyak kehilangan pekerja adalah perdagangan, manufaktur, konstruksi, jasa, dan akomodasi.

\section{METODE PENELITIAN}

Metode yang digunakan oleh penulis dalam penelitian ini adalah studi kepustakaan, yaitu studi yang diperoleh dari berita online serta studi literatur, yaitu penelitian terdahulu, penulis akan menyajikan tiga penelitian terdahulu untuk mencari bagaimana cara pemerintah dalam mengatasi pengangguran. Data yang diperoleh selanjutnya diolah dengan metode deskriptif serta dalam bentuk tabel untuk menganalisis dampak pandemi COVID-19 terhadap pengangguran yang terjadi di Indonesia. Penelitian ini dilakukan untuk mengetahui hubungan antara COVID-19 dan pengangguran dengan melihat pengaruh di antara COVID-19 dan pengangguran.

\section{HASIL PENELITIAN DAN PEMBAHASAN}

\subsection{Hasil dan Pembahasan Penelitian}

\subsubsection{Pengangguran di Indonesia Terdampak Pandemi COVID-19}

Indonesia menjadi salah satu negara yang terdampak pandemi COVID-19, dengan kasus tersebut pertama kali muncul pada awal bulan Maret 2020 dan masih berlangsung hingga saat ini. Pandemi ini menyebabkan banyak kematian dan Indonesia menempati peringkat ketiga jumlah kematian akibat COVID-19 terbanyak di Asia (Worldometer, 2020). Sebagai tanggapan terhadap pandemi COVID-19 tersebut, pemerintah memberlakukan Pembatasan Sosial Berskala Besar (PSBB) di sebagian besar wilayah di Indonesia. Hal ini dilakukan untuk mencegah kemungkinan penyebaran makin meluas. Dalam masa PSBB, sejumlah kegiatan yang melibatkan publik dibatasi, misalnya beberapa sektor perkantoran atau instansi diliburkan, pembatasan kegiatan keagamaan, dan pembatasan transportasi umum. Pemerintah juga mengeluarkan kebijakan untuk Work from Home (WFH) dan School from Home (SFH).

Akibat terjadinya pandemi COVID-19 dan PSBB ini, Indonesia mengalami penurunan pendapatan, pelemahan nilai tukar rupiah, dan perlambatan pertumbuhan ekonomi. Pertumbuhan ekonomi Indonesia mengalami penurunan sebagai dampak dari PSBB yang membuat aktivitas masyarakat dalam kegiatan ekonomi menjadi terbatas. Menurut laporan Badan Pusat Statistik (BPS) pada bulan Agustus 2020, "Pertumbuhan ekonomi Indonesia pada kuartal II 2020 sebesar minus 5,32\%" dan menurut Menteri Keuangan Sri Mulyani Indrawati dalam konferensi pers APBN KiTa secara virtual, "Pertumbuhan ekonomi Indonesia pada kuartal III 2020 akan bertumbuh dengan kisaran minus 2,9\% sampai dengan minus 1,1\%" (Fauzia, 2020). Oleh karena itu, kinerja perekonomian yang mengalami penurunan ini juga mempengaruhi ketenagakerjaan di Indonesia, yakni meningkatnya jumlah pengangguran. Selain itu, juga berdampak pada beberapa sektor, oleh karena melemahnya perekonomian Indonesia, beberapa pengusaha tidak memiliki cashflow sehingga perusahaan melakukan PHK (Pemutusan Hubungan Kerja) kepada beberapa pekerja atau buruh. Menurut Analisis Big Data Badan Pusat Statistik (BPS), jumlah lowongan kerja terus berkurang menjadi 62\% per Mei 2020 dibandingkan dengan Februari 2020, dengan kata lain permintaan tenaga kerja mengalami anjlok (Thomas, 2020).

Sementara itu, menurut penelitian terdahulu milik Indayani dan Hartono (2020) dalam studi tentang "Analisis Pengangguran dan Pertumbuhan Ekonomi sebagai Akibat Pandemi 
COVID-19", ada beberapa faktor yang menjadi penyebab adanya pengangguran, berikut ini adalah faktor-faktor penyebab pengangguran menurut Indayani dan Hartono (2020) yaitu:

1. Faktor kenaikan jumlah penduduk di Indonesia:

"Kenaikan jumlah penduduk dapat menimbulkan angka pengangguran juga mengalami kenaikan. Kenaikan angka pengangguran diakibatkan kenaikan jumlah penduduk yang tidak dapat diserap oleh lapangan pekerjaan yang tersedia."

2. Faktor kondisi lingkungan di sebuah negara:

"Dengan adanya wabah coronavirus ini menyebabkan kegiatan ekonomi menjadi melemah dan terhambat. Perusahaan banyak yang terus melakukan proses produksinya tetapi tidak dapat dibarengi dengan pemasukan atau pendapatan. Sehingga, perusahaan tidak dapat menanggung biaya beban gaji atau upah untuk setiap karyawan. Perusahaan, pada akhirnya memutuskan untuk melakukan pemutusan hubungan kerja (PHK) kepada karyawan. Karyawan yang terkena PHK berasal dari sektor formal dan non formal."

3. Faktor pertumbuhan ekonomi sebuah negara:

"Apabila kondisi pertumbuhan ekonomi suatu negara mengalami kenaikan, maka diharapkan dapat memberikan pengaruh terhadap penurunan jumlah pengangguran. Tetapi, dalam kondisi lingkungan hidup yang dilanda wabah coronavirus ini, pertumbuhan ekonomi mengalami penurunan. Artinya, bahwa apabila kondisi pertumbuhan ekonomi mengalami penurunan, maka dapat berpengaruh terhadap jumlah pengangguran yang mengalami penurunan."

Menurut Indayani dan Hartono (2020), pertumbuhan ekonomi Indonesia pada kuartal I per tahun 2020 yang bertumbuh dengan lambat sebesar 2,97\%. Apabila dibandingkan dengan pertumbuhan ekonomi Indonesia pada kuartal IV per tahun 2019 yang mengalami kenaikan sebesar 5,02\%, itu menunjukkan bahwa perekonomian Indonesia jauh menurun banyak sebesar $2,41 \%$.

\subsubsection{Pengangguran di Indonesia yang Terdampak Pandemi COVID-19}

Sebelum adanya pandemi COVID-19 di Indonesia, menurut BPS jika dihitung dalam 10 tahun terakhir yaitu pada bulan Februari 2010, angka TPT (Tingkat Pengangguran Terbuka) tercatat sebesar 7,14\% sedangkan pada bulan Februari 2020, angka TPT tercatat sebesar 4,99\%. Angka tersebut dalam 10 tahun terakhir menunjukkan kecenderungan menurun (Gusman, 2020). Kemudian, setelah munculnya pandemi COVID-19 di Indonesia, angka TPT pada bulan Februari sebesar 4,99\% telah meningkat banyak menjadi sekitar 6,17\% sampai 6,65\% pada bulan Maret 2020 hanya dalam satu bulan (Rizal, 2020). Menurut BPS pada bulan November 2020, angka TPT pada bulan Agustus 2020 tercatat sebesar 7,07\% atau sebanyak 9,77 juta orang yang menganggur (Jayani, 2020).

i) Tabel Jumlah dan Presentase Penduduk Pengangguran dalam 9 Tahun Terakhir Menurut Data Badan Pusat Statistik (2020):

Jumlah dan Presentase Penduduk Pengangguran (bulan Februari dan Agustus pada tahun 2011-2020)

Presentase (\%) Jumlah (juta orang)

\begin{tabular}{|c|c|c|c|}
\hline \multirow{2}{*}{2011} & Februari & 6.96 & 8.37 \\
\cline { 2 - 4 } & Agustus & 7.48 & 8.68 \\
\hline \multirow{2}{*}{2012} & Februari & 6.37 & 7.75 \\
\cline { 2 - 4 } & Agustus & 6.13 & 7.34 \\
\hline \multirow{2}{*}{2013} & Februari & 5.88 & 7.24 \\
\hline \multirow{2}{*}{2014} & Agustus & 6.17 & 7.41 \\
\hline
\end{tabular}




\begin{tabular}{|c|c|c|c|}
\hline \multirow{2}{*}{2015} & Agustus & 5.94 & 7.24 \\
\cline { 2 - 4 } & Februari & 5.81 & 7.45 \\
\hline \multirow{2}{*}{2016} & Agustus & 6.18 & 7.56 \\
\hline \multirow{2}{*}{2017} & Februari & 5.5 & 7.02 \\
\cline { 2 - 4 } & Agustus & 5.61 & 7.03 \\
\cline { 2 - 4 } & Februari & 5.33 & 7.01 \\
\hline \multirow{2}{*}{2018} & Agustus & 5.5 & 7.04 \\
\hline \multirow{2}{*}{2019} & Februari & 5.13 & 6.96 \\
\cline { 2 - 4 } & Agustus & 5.34 & 7.07 \\
\hline \multirow{2}{*}{2020} & Februari & 5.01 & 6.89 \\
\cline { 2 - 4 } & Agustus & 5.28 & 7.05 \\
\cline { 2 - 4 } & Februari & 7.99 & 6.88 \\
\hline
\end{tabular}

*) Berdasarkan tabel di atas terlihat bahwa tingkat pengangguran terendah terjadi terjadi pada bulan Februari 2020 yaitu 4.99\%. Sedangkan tingkat pengangguran tertinggi terjadi pada bulan Agustus 2011 yaitu 7,48\% dan bulan Agustus 2020 yaitu 7.07\%.

ii) Tabel Jumlah dan Presentase Penduduk Bekerja dalam 9 Tahun Terakhir Menurut Data Badan Pusat Statsitik (2020) ${ }^{11}$ :

*) Berdasarkan tabel di atas terlihat bahwa nilai presentase jumlah penduduk bekerja tertinggi terjadi pada bulan Februari 2020 yaitu 95.06\%, sedangkan nilai presentase jumlah penduduk bekerja terendah terjadi pada bulan Agustus 2011 yaitu 92.52\% dan bulan Agustus 2020 yaitu $92.93 \%$.

\subsubsection{Sektor-Sektor yang Terdampak oleh Pandemi COVID-19}

Pertumbuhan ekonomi Indonesia mengalami penurunan sebagai dampak dari PSBB yang membuat aktivitas masyarakat dalam kegiatan ekonomi menjadi terbatas, dan juga pemerintah mengimbau kepada masyarakat untuk mengikuti protokol kesehatan berupa jaga jarak, tidak boleh ada keramaian, wajib tetap di rumah jika tidak ada keperluan keluar rumah, serta pemerintah mengeluarkan kebijakan untuk Work From Home dan School From Home. Hal ini menyebabkan para pengusaha kesulitan berjualan secara langsung, dan para pelanggan juga kesusahan mendapatkan kebutuhan sehari-hari karena harus tetap di rumah. beberapa sektor atau perusahaan mengalami kebangkrutan atau tidak memiliki cashflow (tidak ada pemasukan atau pendapatan yang dihasilkan untuk bisa memberi gaji atau tunjangan kepada para pekerja) sehingga harus memilih opsi terakhir yaitu PHK (Pemutusan Hubungan Kerja). Hingga bulan Mei 2020, Kamar Dagang Industri (Kadin) mencatat 6 juta pekerja di-PHK dan dirumahkan (Thomas, 2020).

Sektor-sektor yang diketahui telah terdampak oleh pandemi COVID-19, yaitu sektor pariwisata (salah satu faktor untuk perekonomian di Indonesia), sektor UMKM, sektor rumah tangga, sektor keuangan (Firdaus, 2020), sektor tekstil, sektor mall, dan sebagainya (Thomas, 2020). Sektor perdagangan adalah sektor yang paling banyak mengalami pengurangan penyerapan tenaga kerja (berkurang berkisar 677.000 - 953.200 orang pekerja). Sedangkan, sektor kontruksi adalah sektor yang paling banyak mengurangi penyerapan tenaga kerja dengan proporsi sebesar 3,2\% - 4,5\% dari jumlah pekerja di sektor tersebut pada bulan Februari 2020. Kemudian, sektor-sektor yang mungkin masih menyerap tenaga kerja di masa pandemi ini adalah jasa pendidikan, informasi dan komunikasi, jasa kesehatan dan kegiatan sosial, serta jasa keuangan dan asuransi (Rizal, 2020). Sedangkan, menurut Bappenas (Badan Perencanaan Pembangunan Nasional) 2020, sektor yang akan banyak kehilangan pekerja adalah perdagangan, manufaktur, konstruksi, jasa, dan akomodasi. 
Sedangkan, menurut studi dari Indayani dan Hartono (2020), berdasarkan data Kementerian Tenaga Kerja (Kemenaker) per 13 April 2020, dari sektor formal, ada sebanyak 212.394 pekerja yang di-PHK dan sebanyak 1.205.191 pekerja yang dirumahkan. Dari sektor nonformal, tercatat sekitar 282 ribu orang yang tidak memiliki penghasilan. Selain dari Kemenaker, berdasarkan data BP Jamsostek, jumlah pekerja yang di-PHK dan dirumahkan sebanyak 454 ribu orang dari sektor formal, dan 537 ribu orang dari sektor nonformal. Kemudian menurut studi dari Mardiyah dan Nurwati (2020) mengenai "Dampak Pandemi COVID-19 Terhadap Peningkatan Angka Pengangguran di Indonesia”, berdasarkan data Kemenaker per 20 April 2020, ada sektor formal yang dirumahkan dan di-PHK tercatat sebanyak 84.926 perusahaan, dengan jumlah pekerja atau buruh sebanyak 241.431 orang yang di-PHK dan 1.304.777 orang yang dirumahkan. Sementara, ada sektor informal yang tercatat sebanyak 31.444 perusahaan dan jumlah pekerja atau buruh yang di-PHK dan dirumahkan sebanyak 538.385 orang. Berikut ini adalah tabel jumlah pekerja yang di-PHK dari sektor formal dan informal per bulan (2020):

\begin{tabular}{|c|c|c|c|}
\hline $\begin{array}{c}\text { Data Kemenaker per } \\
\text { bulan }(2020)\end{array}$ & Sektor & $\begin{array}{l}\text { Jumlah Pekerja } \\
\text { yang di-PHK }\end{array}$ & $\begin{array}{c}\text { Jumlah Pekerja } \\
\text { yang } \\
\text { dirumahkan }\end{array}$ \\
\hline \multirow{2}{*}{13 April } & Formal & 212.394 & 1.205 .191 \\
\hline & Informal & \multicolumn{2}{|c|}{282 ribu } \\
\hline \multirow{2}{*}{20 April } & Formal & 241.431 & 1.304 .777 \\
\hline & Informal & \multicolumn{2}{|c|}{538.385} \\
\hline \multirow{2}{*}{$\begin{array}{l}1 \text { Mei (Sofuroh, } \\
\text { 2020) }\end{array}$} & Formal & 375.165 & 1.032 .960 \\
\hline & Informal & \multicolumn{2}{|c|}{314.833} \\
\hline \multirow{2}{*}{$\begin{array}{c}27 \text { Mei (CNN } \\
\text { Indonesia, 2020) }\end{array}$} & Formal & 380.221 & 1.058 .284 \\
\hline & Informal & \multicolumn{2}{|c|}{318.959} \\
\hline \multirow{2}{*}{$\begin{array}{l}\text { Agustus (dari Maret } \\
\text { hingga Juli 2020) }\end{array}$} & Formal & 383.645 & 1.132 .117 \\
\hline & Informal & \multicolumn{2}{|c|}{630.905} \\
\hline
\end{tabular}

*) Berdasarkan tabel di atas terlihat bahwa tingkat jumlah pekerja yang di-PHK tertinggi terjadi pada bulan Agustus 2020, sedangkan tingkat jumlah pekerja yang di-PHK terendah terjadi pada awal bulan April 2020.

Di bawah ini adalah tabel jumlah pekerja yang di-PHK di Indonesia dalam 6 tahun terakhir menurut data Kemenaker (Pandamsari dan Alvionita, 2020):

\begin{tabular}{|c|c|}
\hline Tahun & Jumlah pekerja yang di-PHK (dalam ribu orang) \\
\hline 2014 & 77.7 \\
\hline 2015 & 48.8 \\
\hline 2016 & 12.8 \\
\hline 2017 & 9.8 \\
\hline 2018 & 3.4 \\
\hline
\end{tabular}




\begin{tabular}{|c|c|}
\hline $\begin{array}{c}2019 \text { (menurut Asosiasi } \\
\text { Serikat Pekerja) }\end{array}$ & 45 \\
\hline 2020 (per Agustus) & 383.6 \\
\hline
\end{tabular}

*) Berdasarkan tabel di atas terlihat bahwa tingkat jumlah pekerja yang di-PHK tertinggi terjadi pada tahun 2020, sedangkan tingkat jumlah pekerja yang di-PHK terendah terjadi pada tahun 2018.

\subsubsection{Cara Pemerintah Mengatasi Peningkatan Jumlah Pengangguran di Indonesia}

Salah satu faktor dari peningkatan pengangguran yang terdampak pandemi COVID-19 di Indonesia adalah pelemahan perekonomian di Indonesia, dan demi berlangsungnya kegiatan ekonomi masyarakat untuk menafkahi keluarga, pemerintah berusaha mencari jalan untuk mengatasi pengangguran tersebut. Adapun beberapa peneliti akademisi dari berbagai kampus di Indonesia turut membantu mencari jalan untuk mengatasi pengangguran tersebut. Berikut ini adalah beberapa upaya untuk mengatasi pengangguran dari berbagai sumber, yakni:

Menurut Kemenaker (Kementerian Tenaga Kerja), langkah strategis untuk mengatasi pengangguran di masa pandemi COVID-19, yaitu:

1. Langkah pertama, Kemenaker tetap melaksanakan pelatihan berbasis kompetensi dan produktivitas melalui program BLK (Balai Latihan Kerja) Tanggap COVID-19.

2. Langkah kedua, program pengembangan perluasan kesempatan kerja bagi pekerja/buruh terdampak COVID-19 berupa program padat karya dan kewirausahaan.

3. Langkah ketiga, Kemenaker juga telah membuka layanan informasi, konsultasi, dan pengaduan bagi pekerja/buruh Keselamatan dan Kesehatan Kerja (K3) di perusahaan (CNBC Indonesia, 2020).

Selain itu, menurut Nur Lella Junaedi (2020), ada tujuh cara jitu mengatasi pengangguran, sebagai berikut:

1. Mengeluarkan Kebijakan Moneter

Bentuk dari kebijakan moneter yang diambil dalam situasi pandemi ini adalah kebijakan moneter ekspansif (monetary expansive policy). Kebijakan moneter ekspansif atau disebut sebagai kebijakan moneter longgar ini merupakan suatu kebijakan dalam rangka menambah uang yang beredar. Kebijakan ini dilakukan untuk mengatasi pengangguran dan meningkatkan daya beli masyarakat (permintaan masyarakat) pada saat perekonomian mengalami resesi atau depresi. Kebijakan tersebut dilakukan dengan menurunkan suku bunga, membeli atau menjual obligasi atau sekuritas pemerintah oleh bank sentral, mengatur nilai tukar mata uang asing dan mengatur ulang jumlah uang yang harus disimpan di bank. Dengan penurunan suku bunga ini dapat menurunkan biaya pinjaman dan mendorong masyarakat supaya masyarakat mau berinvestasi dan berbelanja. Dengan begitu maka proses ekonomi di Indonesia akan kembali normal dan juga industri dapat memproduksi lebih banyak barang atau jasa.

2. Mengeluarkan Kebijakan Fiskal

Apabila kebijakan moneter masih kurang efektif untuk memulihkan ekonomi, maka cara lain yang bisa dilakukan adalah dengan mengeluarkan kebijakan fiskal. Kebijakan fiskal ini merupakan kebijakan yang dikeluarkan oleh pemerintah terutama Kementerian Keuangan (Kemenkeu) dengan cara memotong pajak dan meningkatkan jumlah pengeluaran negara supaya dapat memacu pertumbuhan ekonomi negara Indonesia. Kebijakan fiskal juga selalu disebut sebagai cara untuk mengatasi pengangguran siklis, karena faktor yang menjadi penyebab dari pengangguran ini adalah fluktuasi ekonomi (kenaikan dan penurunan aktivitas ekonomi secara relatif) seperti adanya resesi atau depresi. Dengan kebijakan fiskal ini, dapat membantu meningkatkan pendapatan dan konsumsi masyarakat yang mengarah pada permintaan agregat yang lebih 
tinggi. Peningkatan permintaan agregat yang tinggi ini dapat mempengaruhi pada peningkatan jumlah PDB (Produk Domestik Bruto). Jika jumlah PDB tinggi pada waktu tertentu atau setahun terakhir, maka itu menunjukkan bahwa proses produksi barang dan jasa akan kembali menjadi normal dan jumlah pengangguran akan berkurang pula.

3. Memberikan Pendidikan dan Pelatihan (Program Kartu Prakerja)

Pemutusan hubungan kerja (PHK) sering terjadi karena sumber daya manusia (SDM) telah dianggap tidak sesuai dengan kebutuhan perusahaan. Salah satu penyebabnya karena SDM digantikan dengan robot (pengangguran teknologi). Oleh sebab itu, upaya untuk mengatasi pengangguran teknologi tersebut yaitu dengan memberikan pendidikan dan keterampilan baru. Upaya tersebut sebenarnya sempat dilakukan oleh pemerintah dengan meluncurkan program Kartu Prakerja bagi pekerja yang menganggur. Dengan program Kartu PraKerja tersebut, masyarakat dapat mempelajari berbagai macam keterampilan baru melalui kursus secara daring.

4. Pemberian Subsidi Ketenagakerjaan

Cara lain untuk mengatasi pengangguran yaitu dengan memberikan subsidi berupa keringanan pajak untuk para pengusaha atau subsidi kepada para pengangguran. Akan tetapi, cara tersebut memang membutuhkan dana yang banyak sekali, apalagi jika jumlah pengangguran atau perusahaan yang perlu diberikan subsidi cukup banyak. Meskipun begitu, ada dua langkah yang sebetulnya sudah dilakukan oleh pemerintah saat ini, yakni dengan memberikan keringanan pajak bagi lebih dari ratusan ribu perusahaan yang terdampak pandemi COVID-19, serta memberikan bantuan subsidi bagi yang terkena PHK melalui program Kartu Prakerja.

5. Perpanjangan Tunjangan Ketenagakerjaan

Perpanjangan tunjangan ketenagakerjaan ini merupakan perpanjangan tunjangan bagi para pencari kerja yang telah memenuhi syarat tertentu dan diketahui sebagai pengangguran yang disebabkan oleh PHK dari perusahaannya.

6. Melakukan Diversifikasi Ekonomi

Pandemi COVID-19 ini telah menyebabkan perekonomian daerah yang biasanya bergantung pada sektor pariwisata menjadi hancur. Selain itu, tempat wisata pun menjadi sepi karena tidak adanya pengunjung wisata sehingga menimbulkan banyak pekerja dari tempat wisata menjadi pengangguran. Untuk mengatasi hal tersebut, pemerintah dapat mengeluarkan kebijakan diversifikasi ekonomi. Kebijakan tersebut merupakan cara memunculkan berbagai macam produk atau bidang usaha yang diyakini mampu meningkatkan perekonomian. Diversifikasi ekonomi ini bertujuan supaya masyarakat tidak hanya mengandalkan pada satu jenis usaha saja tetapi juga berbagai macam usaha. Upaya ini juga diyakini sebagai salah satu cara mengatasi pengangguran musiman yang sering terjadi ketika tempat wisata menjadi sepi.

7. Menyediakan Banyak Informasi Lowongan Kerja

Cara terakhir untuk mengatasi pengangguran yang dapat dilakukan yaitu pemerintah dapat menyediakan banyak info lowongan kerja yang valid bagi para pencari kerja melalui kerja sama dengan platform penyedia info lowongan kerja dan perusahaan yang masih membuka lowongan kerja melalui bursa kerja online. Upaya tersebut juga merupakan cara untuk mengatasi pengangguran friksional bagi pencari kerja yang selalu kesulitan dalam mencari pekerjaan yang cocok.

Menurut studi dari Mardiyah dan Nurwati (2020), pemerintah telah memiliki beberapa program jaring pengaman sosial untuk mengatasi dampak pandemi COVID-19 terhadap kehidupan masyarakat, salah satunya adalah program Kartu Prakerja, pada tahun 2020, pemerintah telah menaikkan anggaran untuk program Kartu Prakerja dari Rp 10 triliun menjadi Rp 20 triliun. Sementara itu, menurut studi dari Aulawi (2020) mengenai "Penerbitan Peraturan 
Pemerintah Pengganti UU No 1 tahun 2020 sebagai Strategi Kebijakan Pajak Pemerintah Indonesia dalam Menghadapi Dampak Pandemi COVID-19 terhadap Keuangan Negara”, dalam menghadapi pandemi COVID-19, pemerintah menerapkan berbagai kebijakan perpajakan untuk menjaga kestabilan perekonomian Indonesia. "Kebijakan perpajakan dalam peraturan pemerintah pengganti UU No. 1 Tahun 2020, yakni: 1) Penyesuaian tarif Pajak Penghasilan Wajib Pajak badan dalam negeri dan bentuk usaha tetap, 2) Perlakuan perpajakan dalam kegiatan Perdagangan Melalui Sistem Elektronik (PMSE), 3) Perpanjangan waktu pelaksanaan hak dan pemenuhan kewajiban perpajakan, serta 4) Pemberian kewenangan kepada Menteri Keuangan untuk memberikan fasilitas kepabeanan berupa pembebasan atau keringanan bea masuk dalam rangka penanganan kondisi darurat serta pemulihan dan penguatan ekonomi nasional". Menurut Mardiyah dan Nurwati (2020), agar kebijakan perpajakan tersebut menjadi lebih efektif, maka diperlukan upaya pendukung lainnya untuk meningkatkan pertahanan dalam perekonomian Indonesia. Upaya pendukung tersebut adalah kebijakan relaksasi pajak, dan salah satu kebijakan tersebut adalah karyawan tidak perlu membayar PPh untuk tanggal 6 April hingga September.

\begin{tabular}{|c|c|c|c|}
\hline \multicolumn{2}{|c|}{$\begin{array}{c}\text { Jumlah dan Presentase } \\
\text { Penduduk Bekerja }\end{array}$} & Presentase (\%) & $\begin{array}{c}\text { Jumlah (juta } \\
\text { orang) }\end{array}$ \\
\hline \multirow{2}{*}{2011} & Februari & 93.04 & 112.04 \\
\cline { 2 - 4 } & Agustus & 92.52 & 107.41 \\
\hline \multirow{2}{*}{2012} & Februari & 93.63 & 114.06 \\
\cline { 2 - 4 } & Agustus & 93.87 & 112.50 \\
\hline \multirow{2}{*}{2013} & Februari & 94.12 & 115.92 \\
\cline { 2 - 4 } & Agustus & 93.83 & 112.76 \\
\hline \multirow{2}{*}{2014} & Februari & 94.3 & 118.16 \\
\cline { 2 - 4 } & Agustus & 94.06 & 114.62 \\
\hline \multirow{2}{*}{2015} & Februari & 94.19 & 120.84 \\
\cline { 2 - 4 } & Agustus & 93.82 & 114.81 \\
\hline \multirow{2}{*}{2016} & Februari & 94.5 & 120.64 \\
\cline { 2 - 4 } & Agustus & 94.39 & 118.41 \\
\hline \multirow{2}{*}{2017} & Februari & 94.67 & 124.53 \\
\cline { 2 - 4 } & Agustus & 94.5 & 121.02 \\
\hline \multirow{2}{*}{2018} & Februari & 94.9 & 129.47 \\
\cline { 2 - 4 } & Agustus & 94.7 & 126.28 \\
\hline \multirow{2}{*}{2019} & Februari & 95.02 & 131.69 \\
\cline { 2 - 4 } & Agustus & 94.77 & 128.14 \\
\hline \multirow{2}{*}{2020} & Februari & 95.06 & 133.29 \\
\cline { 2 - 4 } & Agustus & 92.93 & 128.45 \\
\hline \multirow{2}{*}{20} & & \\
\hline \multirow{2}{*}{2013} & \\
\hline
\end{tabular}

\section{KESIMPULAN}

Dilihat dari pembahasan tersebut di atas, penulis menyimpulkan bahwa:

Pertama, penyebab terjadinya peningkatan pengangguran yang signifikan di Indonesia adalah semua itu bermula dari pandemi COVID-19 sejak awal tahun 2020, yang kemudian sebagai tanggapan pemerintah atas pandemi tersebut, pemerintah mengeluarkan kebijakan PSBB dengan membatasi sejumlah kegiatan publik, dan juga pemerintah mengeluarkan kebijakan untuk Work From Home dan School From Home. Kebijakan tersebut membuat kegiatan ekonomi menjadi terhambat yang mengakibatkan perusahaan tidak mendapat cashflow sehingga tidak dapat 
menanggung biaya beban upah bagi semua pekerja atau buruh. Hal tersebut mendorong perusahaan membuat keputusan terakhir, yakni melakukan pemutusan hubungan kerja (PHK) kepada sebagian pekerja atau buruh, serta jumlah lowongan kerja pun berkurang, hal ini mengakibatkan perekonomian di Indonesia terus melambat dan terhambat. Oleh karena itu, jumlah pengangguran yang terjadi di Indonesia terus meningkat seiring adanya pandemi COVID-19.

Kedua, menurut kedua data jumlah penduduk yang pengangguran dan penduduk bekerja di atas menunjukkan bahwa tingkat jumlah penduduk yang pengangguran tertinggi pada bulan Agustus 2020 merupakan jumlah yang paling besar dalam 9 tahun terahkir. Sementara itu, nilai presentase jumlah penduduk bekerja pada bulan Agustus 2020 merupakan nilai terendah dalam 9 tahun terakhir. Tingkat jumlah penduduk yang pengangguran dan nilai presentase jumlah penduduk bekerja pada bulan Agustus 2020 sama besar dengan bulan Agustus 2011, jadi bisa dikatakan bahwa jumlah tersebut seakan-akan kembali ke tahun 2011. Selain itu, perkembangan dari tahun 2011 hingga Februari 2020 jumlah penduduk yang pengangguran justru berkurang sedangkan jumlah penduduk bekerja cenderung bertambah. Jadi sebelum ada pandemi COVID-19, perkembangan jumlah pengangguran dan penduduk bekerja justru berjalan dengan normal, sedangkan setelah ada pandemi COVID-19, jumlah pengangguran meningkat banyak dan jumlah penduduk bekerja berkurang banyak pula.

Ketiga, dari data jumlah pekerja yang di-PHK dari sektor formal dan informal dalam tabel terlihat bahwa jumlah pekerja yang di-PHK dan dirumahkan yang terus menerus bertambah secara tidak normal. Itu dapat menyebabkan banyak sekali pekerja yang menganggur. Menurut penulis, pekerja yang dirumahkan mungkin ada yang tidak mengerti dengan teknologi atau misalnya suatu sistem aplikasi atau perangkat pendukung khusus untuk kegiatan pekerjaan di perusahaan tidak ada di dalam laptop atau komputer di rumah sehingga pekerja kesulitan untuk bekerja, oleh karena masalah tersebut tidak akan bisa membantu menjaga kestabilan perusahaan.

Keempat, dari pembahasan di atas ada banyak sekali upaya untuk mengatasi peningkatan jumlah pengangguran di Indonesia dari berbagai pihak misalnya di pembahasan ada pihak pemerintah dengan Kemenaker, peneliti dengan Nur Lella Junaedi dan akademisi dengan Mardiyah dan Nurwati. Jadi menurut penulis, upaya-upaya yang dapat dilakukan untuk mengatasi peningkatan jumlah pengangguran tersebut berdasarkan pembahasan di atas, yaitu:

1. Mengeluarkan kebijakan moneter dengan menurunkan suku bunga untuk meringankan biaya pinjaman bagi masyarakat.

2. Mengeluarkan kebijakan fiskal dengan memotong pajak dan meningkatkan pengeluaran negara supaya perekonomian Indonesia membaik.

3. Memberikan pelatihan kerja melalui program Kartu PraKerja supaya pekerja yang terkena PHK dapat bekerja lagi dan meningkatkan jumlah penduduk bekerja.

4. Memberikan subsidi berupa keringanan pajak bagi para pengusaha supaya para pengusaha tetap menjalankan usahanya.

5. Melakukan diversifikasi ekonomi dengan mencari usaha baru dengan produk barang dan jasa yang dapat membantu mendapatkan pendapatan seperti pengusaha fashion dapat membuat pakaian pelindung diri kesehatan, masker dan lainnya.

6. Memberikan perpanjangan waktu untuk membayar pajak.

\section{UCAPAN TERIMAKASIH}

Terimakasih kepada Sekolah Tinggi Ilmu Ekonomi Media Nusantara Citra

\section{DAFTAR PUSTAKA}

Aswani, Tuti. 2020. Hindari Lansia Dari COVID-19. Diakses pada tanggal 2 November 2020 dari www.padk.kemkes.go.id/article/read/2020/04/23/21/hindari-lansia-dari-covid-19.html 
Aulawi, Anton. 2020. Penerbitan Peraturan Pemerintah Pengganti Undang-Undang Nomor 1 Tahun 2020 Sebagai Strategi Kebijakan Pajak Pemerintah Indonesia Dalam Menghadapi Dampak Pandemi COVID-19 Terhadap Keuangan Negara. Diakses pada tanggal 28 Januari 2021 dari http://ejournal.lppm-unbaja.ac.id/index.php/progress/article/view/936/533

BPS. 2020. Tabel Dinamis. Diakses pada tanggal 6 Februari 2021 dari https://www.bps.go.id/site/resultTab

CNBC Indonesia. 2020. Langkah Strategis Menaker Atasi Pengangguran di Masa COVID-19. Diakses pada tanggal 1 November 2020 dari https://www.cnbcindonesia.com/news/20200630201804-4169239/langkah-strategis-menaker-atasi-pengangguran-di-masa-covid-19

CNN Indonesia. 2020. Pekerja Dirumahkan dan Kena PHK Akibat Corona Capai 3,05 Juta. Diakses pada tanggal 8 Februari 2021 dari https://www.cnnindonesia.com/ekonomi/20200720114203-92526610/pekerja-dirumahkan-dan-kena-phk-akibat-corona-capai-305-juta

Fauzia, Mutia. 2020. Sri Mulyani Proyeksi Ekonomi Kuartal III Minus 29 Persen, Siap-Siap Resesi. Diakses pada tanggal 11 November 2020 dari https://money.kompas.com/read/2020/09/22/125539726/sri-mulyani-proyeksi-ekonomikuartal-iii-minus-29-persen-siap-siap-resesi?page=all

Firdaus, Rivaldi. 2020. Dampak Perekonomian di Indonesia Selama Pandemi COVID-19. Diakses pada $\begin{array}{lllll}\text { tanggal } & 19 & \text { November } & 2020 & \text { dari }\end{array}$ https://www.kompasiana.com/rivaldifirdaus1407/5e9575f8d541df16776d47c2/dampakperekonomian-di-indonesia-selama-pandemi-covid-19

Indayani, Hartono. 2020. Analisis Pengangguran dan Pertumbuhan Ekonomi sebagai Akibat Pandemi COVID-19. Diakses pada tanggal 28 Januari 2021 dari https://ejournal.bsi.ac.id/ejurnal/index.php/perspektif/article/view/8581

Jayani, Dwi Hadya. 2020. Terdampak COVID-19, Pengangguran Bertambah Jadi 9,77 Juta Orang per Agustus 2020. Diakses pada tanggal 19 Januari 2021 dari https://databoks.katadata.co.id/datapublish/2020/11/05/terdampak-covid-19-pengangguranbertambah-jadi-977-juta-orang-per-agustus-

2020\#: :text=Pandemi\%20Covid\%2D19\%20berdampak\%20terhadap,menjadi\%20138\%2C2 2\%20juta\%20orang

Junaedi, Nur Lella. 2020. 7 Cara Jitu Mengatasi Pengangguran. Diakses pada tanggal 1 November 2020 dari https://www.ekrut.com/media/cara-mengatasi-pengangguran

Konsep Pengangguran. Diakses pada tanggal 19 November 2020 dari https://osf.io/p43wt/download\#: :text=Berdasarkan\%20uraian\%20di\%20atas\%20dapat,seharus nya)\%2C\%20d)\%20kegiatan\%20perekonomian

Mardiyah, Nurwati. 2020. Dampak Pandemi COVID-19 Terhadap Peningkatan Angka Pengangguran di Indonesia. Diakses pada tanggal 28 Januari 2021 dari https://www.academia.edu/download/63135109/Artikel_Studi_Kependudukan_Rahma_Ainul_ Mardiyah_17031018007620200429-102148-10xmp8n.pdf

P2PTM Kemenkes RI. 2020. Sobat Sehat, Lawan Covid-19 Dengan Menerapkan 3M. Diakses pada tanggal 16 Februari 2021 dari http://www.p2ptm.kemkes.go.id/infographic-p2ptm/penyakitparu-kronik/page/2/sobat-sehat-lawan-covid-19-dengan-menerapkan-3m

Pandamsari dan Alvionita. 2020. Angka Pengangguran berpotensi Double Digit di Akhir 2020. Diakses pada tanggal 8 Februari 2021 dari https://lokadata.id/artikel/angka-pengangguran-berpotensidouble-digit-di-akhir-2020

Pandemi COVID-19 di Indonesia. Diakses pada tanggal 13 Oktober 2020 dari https://id.wikipedia.org/wiki/Pandemi_COVID-19

Rizal, Jawahir Gustav. 2020. Pandemi COVID-19, Apa Saja Dampak pada Sektor Ketenagakerjaan Indonesia? Diakses pada tanggal 26 Oktober 2020 
Sandi, Ferry. 2020. Pemerintah Klaim Baru 2,1 Juta Pekerja Kena PHK-Dirumahkan. Diakses pada tanggal 8 Februari 2021

Sirusa BPS. 2020. Daftar Istilah. Diakses pada tanggal 19 November 2020 dari https://sirusa.bps.go.id/sirusa/index.php/istilah/index

Sofuroh, Faidah Umu. 2020. Data Kemenaker: Pekerja Terdampak COVID-19 Capai Sekitar 3 Juta Orang. Diakses pada tanggal 8 Februari 2021

Thomas, Vincent Fabian. 2020. Angka Pengangguran 2020 Terburuk, Apa yang Bisa Dilakukan Jokowi? Diakses pada tanggal 26 Oktober 2020

\section{BIOGRAFI PENULIS}

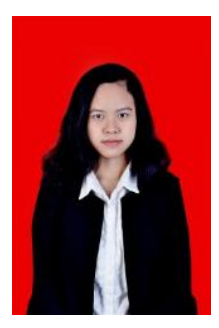

Nama : Verina Ruth Krisnandika

Afiliasi : Sekolah Tinggi Media Nusantara Citra

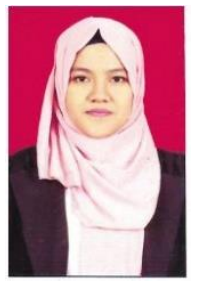

Nama : Darlin Aulia, S.E., M.S.Ak

Afiliasi : Sekolah Tinggi Media Nusantara Citra

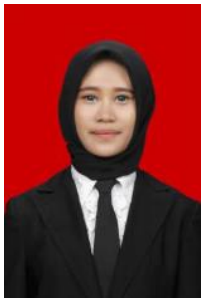

Nama : Luluul Jannah

Afiliasi :Sekolah Tinggi Media Nusantara Citra 